\title{
QUADRICEPS AUTOGRAFT IN ANTERIOR CRUCIATE LIGAMENT RECONSTRUCTION: A LITERATURE REVIEW
}

\author{
AUTOENXERTO DE QUADRÍCEPS NA RECONSTRUÇÃO DO LIGAMENTO CRUZADO ANTERIOR: \\ UMA REVISÃO DA LITERATURA
}

ReVIeW ARTicle

ARTIGO DE REVISÃO

Artículo de ReVISIÓN

\author{
AUTOINJERTO DE CUÁDRICEPS EN LA RECONSTRUCCIÓN DEL LIGAMENTO CRUZADO ANTERIOR: \\ UNA REVISIÓN DE LA LITERATURA
}

\author{
Victor Eduardo Roman Salas' \\ (Physician) \\ Diego Escudeiro de Oliveira' (ID \\ (Physician) \\ Marcos Vaz de Lima' (ID \\ (Physician) \\ Aires Duarte Junior ${ }^{1}$ (ID \\ (Physician) \\ Luiz Gabriel Betoni Guglielmetti' (ID) \\ (Physician) \\ Ricardo de Paula Leite Cury ${ }^{1}$ (ID \\ (Physician) \\ Pedro Baches Jorge' 1 (ID \\ (Physician) \\ 1. Irmandade de Misericórdia \\ da Santa Casa de São Paulo, \\ Department of Orthopedics and \\ Traumatology, Sports Trauma \\ Group, São Paulo, SP, Brazil.
}

\section{Correspondence:}

Victor Eduardo Roman Salas Sports Trauma Group, Department of Orthopedics and Traumatology Irmandade de Misericórdia da Santa Casa de São Paulo.

Rua Cesário Mota Junior, 112, Vila Buarque, São Paulo, SP, Brazil. 01221-020.

victor88salas@gmail.com

\begin{abstract}
Introduction: Anterior cruciate ligament injury is one of the most prevalent musculoskeletal injuries. Therefore, several surgical techniques and graft types have been described for its reconstruction. Autologous hamstring tendon graft is one of the most frequently used, but use of the quadriceps tendon graft has gained prominence in recent years. Objective: To review the literature to compare the outcomes of patients undergoing anterior cruciate ligament reconstruction (ACLR) with quadriceps tendon (QT) autograft versus hamstring tendon (HT) autograft. Methods: A literature review was conducted through PubMed to locate studies (Level of evidence I-III) comparing the outcomes of the QT autograft vs. the HT autograft in patients undergoing primary ACL reconstruction. Patients were assessed on the basis of re-rupture rate, ligament instability, patient-reported outcome scores, previous pain, and isokinetic tests. Results: Six studies were selected according to inclusion criteria. A total of 481 patients were evaluated, 243 in the QT group and 238 in the HT group. The total re-rupture rate was 1.6\% (8 of 481), with 6 in the HT group and 2 in the QT group, but with no statistical difference between groups. One study found increased ligament instability in the HT group and another study found greater instability in the QT group, both with statistical significance. Regarding the patient-reported functional scores, only 01 study found statistical difference, with better results in the QT group. There was no difference in previous pain between groups in the selected studies. Regarding the isokinetic test, one study found a difference in flexor force in the HT group ( $p<0.01$ ), with no difference in extensor force, while another two studies found an increased extensor force deficit in the QT group within up to 01 year of follow-up. The flexor/ extensor muscle strength ratio was higher in the QT group in both studies. Conclusion: ACL reconstruction with QT graft presents re-rupture rates, ligament instability, functional scores and donor site morbidity that are similar to the $\mathrm{HT}$ graft, in addition to preserving greater flexor force in proportion to extensor force. Level of evidence: IV; Review study.
\end{abstract}

Keywords: Anterior cruciate ligament reconstruction; Quadriceps muscle; Hamstring tendons; Transplantation, autologous.

\section{RESUMO}

Introdução: A lesão do ligamento cruzado anterioréuma das lesões musculoesqueléticas mais prevalentes. Sendo assim, diversas técnicas cirúrgicas e tipos de enxerto foram descritos para sua reconstrução. O enxerto autólogo do tendão dos músculos isquiotibiais éum dos mais utilizados, porém o uso do enxerto do tendão do músculo quadríceps ganhou destaque nos últimos anos. Objetivo: Revisar a literatura para comparar os desfechos de pacientes submetidos à reconstrução do ligamento cruzado anterior ( $R L C A$ ) com autoenxerto do tendão do músculo quadríceps (TQ) versus autoenxerto dos tendões dos músculos isquiotibiais (TF). Métodos: Uma revisão da literatura foi realizada por meio do PubMed para localização dos estudos (Nível de evidência I-III) que comparam os desfechos dos pacientes submetidos à reconstrução primária do LCA com autoenxerto TQ versus autoenxerto TF. Os pacientes foram avaliados com base na taxa de re-ruptura, instabilidade ligamentar, escores de resultados relatados pelo paciente, dor prévia e teste isocinético. Resultados: Seis estudos foram selecionados conforme o critério de inclusão. Um total de 481 pacientes foi avaliado, 243 no grupo TQ e 238 no grupo TF. O índice total de re-ruptura foi de 1,6\% (8 de 481), sendo seis no grupo TF e dois no grupo TQ, porém sem diferença estatística entre os grupos. Um estudo encontrou instabilidade ligamentar aumentada no grupo TF e outro estudo verificou uma maior instabilidade no grupo TQ, ambos com significância estatística. Em relação aos escores funcionais relatados pelo paciente, somente um estudo encontrou diferença estatística com melhores resultados no grupo TQ. Não houve diferença quanto à dor prévia entre os grupos nos estudos selecionados. Sobre o teste isocinético, um estudo encontrou diferença na força flexora no grupo TF $(p<0,01)$ sem diferença na força extensora, já outros dois estudos encontraram um déficit de força extensora aumentado no grupo TQ em até um ano de seguimento. A razão da força da musculatura flexora/extensora foi maior no grupo TQ nos dois estudos. Conclusão: A reconstrução do LCA com enxerto TQ apresenta índice de re-ruptura, instabilidade ligamentar, escores funcionais e morbidade do sítio doador semelhantes quando comparada com o enxerto TF, além de preservar uma maior força flexora proporcional à força extensora. Nível evidência: IV; Estudo de revisão.

Descritores: Reconstrução do ligamento cruzado anterior; Músculo quadríceps; Tendões dos músculos isquiotibiais; Transplante autólogo. 


\section{RESUMEN}

Introducción: La lesión del ligamento cruzado anterior es una de las lesiones musculoesqueléticas más prevalentes. Siendo así, han sido descritas varias técnicas quirúrgicas y tipos de injerto para su reconstrucción. El injerto autólogo del tendón de los músculos isquiotibiales es uno de los más utilizados, aunque el uso del injerto del tendón del músculo cuádriceps ha cobrado importancia en los últimos años. Objetivo: Revisar la literatura para comparar los desenlaces de pacientes sometidos a la reconstrucción del ligamento cruzado anterior (RLCA) con autoinjerto del tendón del músculo cuádriceps (TQ) versus autoinjerto de los tendones de los músculos isquiotibiales (TF). Métodos: Una revisión de la literatura fue realizada a través del PubMed para localización de los estudios (Nivel de evidencia I-III) que comparan los desenlaces de los pacientes sometidos a la reconstrucción primaria del LCA con autoinjerto TQ versus autoinjerto TF. Los pacientes fueron evaluados con base en la tasa re-ruptura, inestabilidad de los ligamentos, puntuaciones de resultados relatados por el paciente, dolor previo y test isocinético. Resultados: Seis estudios fueron seleccionados de acuerdo al criterio de inclusión. Se evaluó un total de 481 pacientes, 243 en el grupo TQ y 238 en el grupo TF. El índice total de re-ruptura fue del 1,6\% (8 de 481), siendo 6 en el grupo TFy 2 en el grupo TQ, aunque sin diferencia estadística entre los grupos. Un estudio encontró inestabilidad de los ligamentos aumentada en el grupo TF y otro estudio verificó una mayor inestabilidad en el grupo TQ, ambos con significancia estadística. Con relación a los escores funcionales relatados por el paciente, sólo un estudio encontró diferencia estadística, con mejores resultados en el grupo TQ. No hubo diferencia cuanto al dolor previo entre los grupos en los estudios seleccionados. Sobre el test isocinético, un estudio encontró diferencia en la fuerza flexora en el grupo TF $(p<0,01)$ sin diferencia en la fuerza extensora, ya otros dos estudios encontraron un déficit de fuerza extensora aumentado en el grupo TQ en hasta un año de seguimiento. La razón de fuerza de la musculatura flexora/extensora fue mayor en el grupo TQ en los dos estudios. Conclusión: La reconstrucción del LCA con injerto TQ presenta índice de re-ruptura, inestabilidad de los ligamentos, escores funcionales y morbilidad del sitio donante similares cuando comparada con injerto TF, además de preservar una mayor fuerza flexora proporcional a la fuerza extensora. Nivel de evidencia IV; Estudio de revisión.

Descriptores: Reconstrucción del ligamento cruzado anterior; Músculo cuádriceps; Tendones isquiotibiales; Trasplante autólogo.

\section{INTRODUCTION}

Anterior cruciate ligament $(\mathrm{ACL})$ injury is one of the most prevalent musculoskeletal injuries. 'Arthroscopic ACL reconstruction has been described since the $80 \mathrm{~s}^{2}$ and the discussion regarding graft choice continues. Patellar tendon (PT) graft was initially considered the gold standard in ACL reconstruction. ${ }^{3-6}$ After the hamstring tendon (HT) graft became popular, several studies appeared comparing these two grafts. The use of the HT involves lower donor site morbidity, ${ }^{7}$ and some studies ${ }^{8,9}$ have noted that both entail similar clinical outcomes. However, there are reports of a higher rate of re-rupture and ligament instability in patients undergoing $\mathrm{ACL}$ reconstruction with $\mathrm{HT}$. $^{10,11}$

The quadriceps tendon (QT) graft was initially described by Marshall in 1979, ${ }^{12}$ while Blauth ${ }^{13}$ described the use of the midthird quadriceps tendon with patellar bone block in 1984. In 1999, Fulkerson et al. ${ }^{14}$ reviewed this surgical technique by not using bone block, aiming at reducing donor site morbidity and other complications. However, this graft is one of the least used in comparison to HT and PT. ${ }^{15}$

The focus on ligament reconstruction with autologous QT graft recently made a comeback. There are some studies in the literature comparing QT and PT grafts in ACL reconstruction. It is possible to find similar clinical outcome and rate of complications between the two groups, with the advantage of lower donor site morbidity in the QT group. ${ }^{16-20}$

Regarding studies comparing HT and QT, data in the literature are scarce, ${ }^{21-26}$ particularly on comparative studies. The aim of this study is to perform a literature review comparing the clinical outcomes of patients undergoing anterior cruciate ligament reconstruction with QT versus HT.

\section{MATERIALS AND METHODS}

A literature review was performed and two independent reviewers undertook searches in PubMed up to the $31^{\text {st }}$ of July, 2018. The keywords sought were: "anterior cruciate ligament" and "quadriceps muscle".
A total of 833 studies was reviewed by title and abstract. Inclusion criteria were studies that directly compared clinical outcomes in $\mathrm{ACL}$ reconstruction with QT and HT (evidence level I-III) and studies in English. Non-comparative studies or those without an available abstract were excluded. Six studies were selected according to the applied criteria. These studies were not uniform in terms of surgical technique and rehabilitation protocol applied, and will be described in the results. A review study not submitted to the Institutional Review Board.

The outcomes evaluated were (1) donor site morbidity in the presence of previous pain; (2) rate of re-rupture; (3) ligament instability, including ligament tests and anterior laxity measured with an arthrometer (KT-1000 or KT-2000); (4) patient-reported outcome scores such as Lysholm, subjective IKDC, Tergner, KOOS and visual analogue pain scale; and (5) isokinetic test.

\section{RESULTS}

Six studies (level of evidence III) met the inclusion and exclusion criteria, with a total of 243 patients undergoing ACL reconstruction with QT and 238 with HT. The mean follow-up time between studies was 27.4 months (ranging from 12 months to 48 months). There was no significant difference between the cohorts in terms of age, sex, concomitant cartilage injuries or other characteristics in most of the studies included with the exception of Fischer et $\mathrm{al}_{1}{ }^{25}$ in which there was a higher proportion of male patients undergoing reconstruction with $\mathrm{HT}$. The characteristics of the studies and demographic data are described in Table 1.

\section{Surgical technique}

Removal of Quadriceps Graft. The studies were not uniform in terms of the graft removal method and use of bone plug. Only one study ${ }^{23}$ used a minimally invasive technique for graft removal with a suprapatellar transverse incision, while the others used a longitudinal route in the topography of the QT. Most studies used bone plug, except for Martin-Alguacil et al. ${ }^{26}$ 
Removal of Hamstring Graft. Two studies did not describe the HT graft removal method. One study describes removal with a vertical incision in the anteromedial aspect of the tibia over the goose foot (aka pes anserinus), and removal of the graft with an open stripper, maintaining tibial fixation. The other studies used an oblique incision in the goose foot topography and removal of the grafts with a closed stripper.

Preparation of the tunnels and graft fixation. To create the femoral tunnel, two studies ${ }^{21,22}$ used the transtibial technique, three studies ${ }^{23,25,26}$ opted for the anteromedial portal at the anatomical point, and one of these ${ }^{24}$ applied the outside in technique. The creation of the tibial tunnel, which was similar between groups, was performed at the native site of the $A C L$, medial to the lateral meniscus root and lateral to the medial tibial spine. Only one study did not use a bone plug. ${ }^{26}$ In addition, only one of the studies evaluated did not use the same surgical technique as the control group, ${ }^{22}$ since single-bundle ACLR was performed in the QT group and double-bundle ACLR in the HT group. Graft fixation is described in Table 2. Postoperative rehabilitation. Three of the studies $22,23,25$ used a hinged brace from two to six weeks postoperatively. Return to sports was described in only two studies, one within six months ${ }^{22}$ and the other according to the hop test and muscle strength. Only one study did not describe the rehabilitation protocol.

Donor site morbidity. Four studies ${ }^{21-24}$ evaluated morbidity in relation to the donor site of the graft used. In this case, the presence of previous pain was evaluated. None of the studies found differences between groups. Re-rupture rate. Three studies ${ }^{23,24,26}$ evaluated the presence of graft failure in the follow-up performed. None of the studies found a significant difference in the re-rupture rate between groups, yet Martin-Alguacil et al. ${ }^{26}$ discovered an increased tendency for re-rupture in the HT group $\left(X^{2}=3.31, p=0.10\right)$. The re-rupture rate ranged from $0 \%$ to $12 \%$ in the HT group and from 0\% to 3.8\% in the QT group (Table 3).

Ligament instability. Four studies evaluated ligament stability using an arthrometer (KT-100024 and KT-200021,22,26) and ligament tests (Lachman 22,24 and Pivot-shift ${ }^{22,24}$ ). Cavaignac et al. ${ }^{24}$ found greater ligament stability in the QT group with statistical significance compared to the Lachman test and anterior translation measured by arthrometer. Conversely, Sofu et al. ${ }^{21}$ found greater ligament stability in the HT group (Table 4).

Patient-reported functional outcomes. Five ${ }^{21-24,26}$ studies compared patient-reported clinical outcomes between the evaluated groups. All studies used the Lysholm score (Table 5), and only Cavaignac et al. ${ }^{24}$ found statistical difference with better functional result in the QT group $(P<0.05)$. Three ${ }^{22-24}$ studies evaluated
Tegner score and found no statistical difference between groups. Two 22,24 studies evaluated subjective IKDC, also without statistical difference. The KOOM score was evaluated only by Cavaignac et al., ${ }^{24}$ who found statistical difference with better scores in the QT group with respect to pain and return to sports ( $p=0.017$ and $p=0.003$ respectively). The Cincinnati score was evaluated by Martin-Alguacil et al. ${ }^{26}$ and the visual analogue pain scale by Runner et al, ${ }^{23}$ and neither one found any intergroup difference.

Isokinetic Tests. Three $22,25,26$ studies conducted an isokinetic test during follow-up. Lee et al. ${ }^{22}$ found a difference in flexor force at peak torque at 180 degrees/second in the QT group after one year and two years of follow-up. Martin-Alguacil et al. ${ }^{26}$ discovered a difference in the higher flexor/extensor force ratio in the QT group throughout postoperative follow-up, higher peak extensor force in the HT group within one year, and no difference in intergroup flexor force. Fischer et al. ${ }^{25}$ also found a higher flexor/extensor force ratio in the QT group ( $p<0.001)$, lower extensor force in the QT group up to one year of follow-up ( $p<0.001)$, and similar intergroup flexor force.

Table 3. Falha Enxerto.

\begin{tabular}{c|c|c|c|c}
\hline Authors & TQ & TF & Total & P \\
\hline Cavaignac et al. $2017^{24}$ & $1 / 45(2.2 \%)$ & $2 / 41(4.8 \%)$ & $3(3.4 \%)$ & 0.5 \\
\hline Runer et al. $2017^{23}$ & $0 / 40(0 \%)$ & $1 / 40(2.5 \%)$ & $1(1.2 \%)$ & 0.32 \\
\hline Martin-Alguacil et al. $2018^{26}$ & $1 / 26(3.8 \%)$ & $3 / 25(12 \%)$ & $4(7.8 \%)$ & $>0.05$ \\
\hline
\end{tabular}

TQ: tendão quadricptal; TF: tendão isquiotibial.

Table 04. Frouxidão anteroposterior.

\begin{tabular}{c|c|c|c}
\hline Authors & TQ & TF & P \\
\hline Cavaignac et al. $2017^{24 *}$ & $1.1+/-0.9$ & $3.1+/-1.3$ & 0.037 \\
\hline Lee et al $2016^{22 *}$ & $2.1+/-1.9$ & $1.9+/-1.8$ & 0.32 \\
\hline Sofu et al 2013 $3^{21 *}$ & 5.6 & 3.7 & $<0.001$ \\
\hline Martin-Alguacil et al. $2018^{26 * *}$ & 3.3 & 3.1 & 0.719 \\
\hline
\end{tabular}

* Frouxidäo anteroposterior mensurada por artrômetro e em comparação com lado contralateral. Valores descritos em milímetros, como média e desvio padrão. ** Frouxidão anteroposterior mensurada por artrômetro e utilizado valor médio absoluto. Valor em milímetros

Table 5. Escore Lysholm.

\begin{tabular}{c|c|c|c}
\hline Authors & TQ & TF & P \\
\hline Cavaignac et al. $2017^{24}$ & $89+/-6.9$ & $83.1+/-5.3$ & $<0.05$ \\
\hline Lee et al $2016^{22}$ & $92.1+/-8.7$ & $8.4+/-11.9$ & 0.298 \\
\hline Sofu et al 201321 & $\mathrm{ND}^{*}$ & $\mathrm{ND}^{*}$ & $\mathrm{ND}^{*}$ \\
\hline Runer et al $2017^{23}$ & $9.4+/-7.5$ & $93.4+/-8.7$ & $>0.05$ \\
\hline Martin-Alguacil et al. $2018^{26}$ & 93.8 & 92.7 & 0.892 \\
\hline
\end{tabular}

Valores do último seguimento descritos como média e desvio padrão quando disponível. ND: não descrito. Estudo não utilizou valor médio como comparação

Table 1. Características dos estudos e características demográficas dos pacientes do grupo TF versus TQ.

\begin{tabular}{|c|c|c|c|c|c|c|c|c|}
\hline & & $\mathrm{n}$ & & Age, years & & $\mathrm{H} / \mathrm{M}$ & & \\
\hline Authors & Evidence level & TQ & TF & TQ & TF & TQ & TF & Follow up \\
\hline Cavaignac et al. $2017^{24}$ & III & 45 & 41 & $32.1+/-8$ & $30.9+/-9$ & $25 / 20$ & $24 / 17$ & 43 \\
\hline Fischer et al. $2017^{25}$ & III & 61 & 63 & $21.7+/-7.4$ & $21.5+/-6.9$ & $34 / 27$ & $47 / 16$ & 8 \\
\hline Martin-Alguacil et al. $2018^{26}$ & III & 26 & 25 & $18.7+/-3.6$ & $19.2+/-3.6$ & $23 / 2$ & $16 / 9$ & 24 \\
\hline Lee et al. $2016^{22}$ & III & 48 & 48 & $31.1+/-10.0$ & $29.9+/-10.3$ & $44 / 4$ & $44 / 4$ & 35 \\
\hline
\end{tabular}

Nota: dados de idade e seguimento são apresentados como valor médio ou valor médio +/- desvio. Seguimento em meses. TQ: Tendão quadricptal; TF: tendão flexor; H/M: relação homem-mulher;

Table 2. Características das técnicas cirúrgicas do grupo TQ e TF

\begin{tabular}{|c|c|c|c|c|c|c|c|}
\hline & TQ & & & & TF & & \\
\hline Authors & Technique & FF & FT & PO & Technique & FF & FT \\
\hline Cavaignac et al. $2017^{24}$ & A - outside in & PA & PA & com, tíbia & A - outiside in & PA & PA \\
\hline Fischer et al. $2017^{25}$ & $\mathrm{~A}-\mathrm{AM}$ & $\mathrm{BE}$ & PA & com, tíbia & $A-A M$ & $\mathrm{BE}$ & PA \\
\hline Runer et al. $2017^{23}$ & $A-A M$ & $\mathrm{BE}$ & PA + Endotack & com, fêmur & $A-A M$ & $\mathrm{BE}$ & PA +ponto transósseo \\
\hline Martin-Alguacil et al. $2018^{26}$ & $A-A M$ & $\mathrm{PA}$ & PA & sem & $A-A M$ & $\mathrm{BE}$ & PA \\
\hline Lee et al. $2016^{22}$ & Transtibial & PM & PA & com, fêmur & $A-D B$ & $\mathrm{BE}$ & PA \\
\hline Sofu et al. $2013^{21}$ & Transtibial & PM & PA & com, fêmur & Transtibial & Transfemoral & PA \\
\hline
\end{tabular}




\section{DISCUSSION}

The choice of graft in ACL reconstruction is a pertinent and persistent topic of conversation among orthopedists, and different types of graft and clinical outcomes have been described in the literature. The focus on the use of the quadriceps grafts has recently made a comeback. This was initially described by Marshall ${ }^{12}$ in 1987, and later modified by not using patellar bone plug by Fulkerson ${ }^{14}$ in 1999. Despite this modification, only one of the studies evaluated did not use bone plug. ${ }^{26}$

Some series in the literature describe good results with the use of quadriceps grafts. Guimaraes et al., ${ }^{27}$ in a series of patients with a mean follow-up of 10 years, found good results in functional scores, return to sports and donor site morbidity. Chen et al., ${ }^{28}$ in a series with a mean follow-up of four to seven years, also found satisfactory subjective and objective clinical outcomes and discovered that loss of extensor force was minimal.

However, there are few studies comparing QT grafts with other grafts. What we found were subjective clinical outcomes and a similar rate of re-rupture in the QT group and HT groups, with the exception of two authors. Sofu et al. ${ }^{21}$ found increased ligament stability in the HT group. The author attributes this to an increase in biomechanical stress on the reconstructed graft by decreasing the strength and diameter of the remaining quadriceps tendon. This is contradictory in the literature because Adams et al. ${ }^{29}$ found greater force in the donor graft and remaining quadriceps tendon when compared with patellar tendon graft. One of the factors that may explain this difference is that Sofu et al. ${ }^{21}$ did not use the same fixation technique for both groups evaluated, and applied the transtibial technique in ligament reconstruction. In the study described by Cavaignac et al., ${ }^{24}$ functional scores and ligament stability were higher in the QT group, with no deterioration in donor site morbidity.

Diminished muscle strength after $A C L$ reconstruction is associated with a higher risk of knee injury, and recovery of this muscle strength is vital when resuming sport activities. ${ }^{30,31}$ Activation of the hamstring muscles is known to reduce stress on the reconstructed graft, ${ }^{32,33}$ therefore, its preservation may decrease the rate of re-rupture after $A C L$ reconstruction. One of the criteria for resumption of sport activities is $80 \%$ to $90 \%$ extensor force compared to the contralateral side. ${ }^{30,34}$ However, the flexor/extensor force ratio is just as important as absolute strength. ${ }^{33}$ A ratio of $50 \%$ to $80 \% \%^{31,34,35}$ is considered ideal when resuming sport activities. Moreover, it is affirmed in the literature that a ratio above $100 \%$ is a protective factor for ACL injury. ${ }^{36}$ Three ${ }^{22,25,26}$ studies conducted isokinetic tests during postoperative follow-up. Lee et al. ${ }^{22}$ found greater and faster flexor force recovery in the QT group, with no difference in extensor force, but the same author did not describe the flexor/extensor force ratio. Martin-Alguacil et al. ${ }^{26}$ and Fischer et al. ${ }^{25}$ found a better flexor/extensor force ratio in the QT group up to one year of follow-up, but both authors found lower extensor force in this group. These findings suggest that the use of quadriceps grafts, despite violating the extensor mechanism with a decrease in its strength, preserves flexor force. This can be advantageous in ACL reconstruction, especially in the first months after surgery.

The use of quadriceps grafts has promising results with good long-term clinical outcomes and low donor site morbidity. However, there are reports in the literature of complications in QT graft removal, ranging from patellar fracture and excessive bleeding when the graft comes into contact with perforating vessels of the quadriceps muscles, ${ }^{37}$ to cosmetic deformities with femoral muscle retraction. ${ }^{38}$

There are some limitations to this study. Only six comparative studies are available in the literature with level of evidence III, and these were not consistent in terms of the surgical technique employed.

\section{CONCLUSION}

$\mathrm{ACL}$ reconstruction with QT graft has similar re-rupture rates, ligament instability, functional scores and donor site morbidity as the HT graft, besides preserving greater flexor force proportional to extensor force.

All authors declare no potential conflict of interest related to this article

AUTHORS' CONTRIBUTIONS: Each author made significant individual contributions to this manuscript. VERS, DEO: were the main contributors in the writing of the manuscript; MVL, ADJ, LGBG, RPLC, PBJ: performed the literature search, reviewed the manuscript, and contributed to the intellectual concept of the study. All authors participated and approved the final version of the manuscript.

\section{REFERENCES}

1. Gianotti SM, Marshall SW, Hume PA, Bunt L. Incidence of anterior cruciate ligament injury and other knee ligament injuries: a national population-based study. J Sci Med Sport. 2009;12(6):622-7.

2. Sonnery-Cottet $B$, Chambat P. Anatomic double bundle: a new concept in anterior cruciate ligament reconstruction using the quadriceps tendon. Arthroscopy. 2006;22(11):1249.e1-4.

3. Erickson BJ, Harris JD, Fillingham YA, Frank RM, Bush-Joseph CA, Bach BR Jr, et al. Anterior cruciate ligament reconstruction practice patterns by NFL and NCAA football team physicians. Arthroscopy. 2014;30(6):731-8.

4. Carmichael JR, Cross MJ. Why bone-patella tendon-bon grafts should still be considered the gold standard for anterior cruciate ligament reconstruction. Br J Sports Med. 2009;43(5):323-5.

5. Ardern $\mathrm{CL}$, Webster KE, Taylor NF, Feller JA. Hamstring strength recovery after hamstring tendon harvest for anterior cruciate ligament reconstruction: a comparison between graft types. Arthroscopy. 2010;26(4):462-9.

6. Ageberg E, Roos HP, Silbernagel KG, Thomeé R, Roos EM. Knee extension and flexion muscle power after anterior cruciate ligament reconstruction with patellar tendon graft or hamstring tendons graft: a cross-sectional comparison 3 years post surgery. Knee Surg Sports Traumatol Arthrosc. 2009;17(2):162-9.

7. Laxdal G, Kartus J, Hansson L, Heidvall M, Ejerhed L, Karlsson J. A prospective randomized comparison of bone-patellar tendon-bone and hamstring grafts for anterior cruciate ligament reconstruction. Arthroscopy. 2005;21(1):34-42.

8. Holm I, Oiestad BE, Risberg MA, Aune AK. No difference in knee function or prevalence of osteoarthritis after reconstruction of the anterior cruciate ligament with 4-strand hamstring autograft versus patellar tendon-bone autograft: a randomized study with 10-year follow-up. Am J Sports Med. 2010;38(3):448-54.

9. Eriksson K, Anderberg P, Hamberg P, Lofgren AC, Bredenberg M, Westman I, et al. A comparison of quadruple semitendinosus and patellar tendon grafts in reconstruction of the anterior cruciate ligament. J Bone Joint Surg Br. 2001;83(3):348-54.
10. Biau Dj, Katsahian S, Kartus J, Harilainen A, Feller JA, Sajovic M, et al. Patellar tendon versus hamstring tendon autografts for reconstructing the anterior cruciate ligament: A meta-analysis based on individual patient data. Am J Sports Med. 2009;37(12):2470-8.

11. Xie X, Liu X, Chen Z, YuY, Peng S, Li Q. A meta-analysis of bone-patellar tendon-bone autograft versus four-strand hamstring tendon autograft for anterior cruciate ligament reconstruction. Knee. 2015;22(2):100-10.

12. Marshall JL, Warren RF, Wickiewicz TL, Reider B. The anterior cruciate ligament: a technique of repair and reconstruction. Clin Orthop Relat Res 1979;(143):97-106

13. Blauth W. 2-strip substitution-plasty of the anterior cruciate ligament with the quadriceps tendon. Unfallheilkunde. 1984;87(2):45-51.

14. Fulkerson JP, Langeland R. An alternative cruciate reconstruction graft: the central quadriceps tendon. Arthroscopy. 1995; 11(2):252-4

15. Farber J, Harris JD, Kolstad K, McCulloch PC. Treatment of anterior cruciate ligament injuries by Major League Soccer team physicians. Orthop J Sports Med. 2014;2(11):2325967114559892.

16. Gorschewsky O, Klakow A, Pütz A, Mahn H, Neumann W. Clinical comparison of the autologous quadriceps tendon (BQT) and the autologous patella tendon (BPTB) for the reconstruction of the anterior cruciate ligament. Knee Surg Sports Traumatol Arthrosc. 2007;15(11):1284-92

17. Han HS, Seong SC, Lee S, Lee MC. Anterior cruciate ligament reconstruction: quadriceps versus patellar autograft. Clin Orthop Relat Res. 2008;466(1):198-204.

18. Sarrafan N, Mehdinasab SA. Anterior cruciate ligament reconstruction using the patella tendon and quadriceps tendon: a comparative study. Pak J Med Sci. 2008;24:416-9.

19. Kim SJ, Jo SB, Kumar P, Oh KS. Comparison of single and double-bundle anterior cruciate ligament reconstruction using quadriceps tendon-bone autografts. Arthroscopy. 2009;25(1):70-7.

20. Lund B, Nielsen T, Fauno P, Christiansen SE, Lind M. Is quadriceps tendon a better graft choice than patellar tendon? A prospective randomized study. Arthroscopy. 2014;30(5):593-8. 
21. Sofu H, Sahin V, Gursu S, Yildirim T, Issin A, Ordueri M. Use of quadriceps tendon versus hamstring tendon autograft for arthroscopic anterior cruciate ligament reconstruction: A comparative analysis of clinical results. Eklem Hastalik Cerrahisi. 2013;24(3):139-43.

22. Lee JK, Lee S, Lee MC. Outcomes of anatomic anterior cruciate ligament reconstruction: bone quadriceps tendon graft versus double-bundle hamstring tendon graft. Am J Sports Med. 2016;44(9):2323-9.

23. Runer A, Wierer G, Herbst E, Hepperger C, Herbort M, Gfölller $P$, et al. There is no difference between quadriceps- and hamstring tendon autografts in primary anterior cruciate ligament reconstruction: A 2-year patient-reported outcome study. Knee Surg Sports Traumatol Arthrosc. 2018;26(2):605-14.

24. Cavaignac E, Coulin B, Tscholl P, Nik Mohd Fatmy N, Duthon V, Menetrey J. Is quadriceps tendon autograft a better choice than hamstring autograft for anterior cruciate ligament reconstruction? A comparative study with a mean follow-up of 3.6 years. Am J Sports Med. 2017;45(6):1326-32.

25. Fischer F, Fink C, Herbst E, Hoser C, Hepperger C, Blank C, et al. Higher hamstring-to-quadriceps isokinetic strength ratio during the first post-operative months in patients with quadriceps tendon compared to hamstring tendon graft following ACL reconstruction. Knee Surg Sports Traumatol Arthrosc. 2018;26(2):418-25.

26. Martin-Alguacil JL, Arroyo-Morales M, Martín-Gomez JL, Monje Cabrera IM, Abellán-Guillén JF, Esparza-Ros $F$, et al. Strength recovery after anterior cruciate ligament reconstruction with quadriceps tendon versus hamstring tendon autografts in soccer players: A randomized controlled trial. Knee. 2018;25(4):704-14.

27. Guimaraes MV, Junior LH, Terra DL. Reconstruction of the anterior cruciate ligament with the central third of the quadriceps muscle tendon: analysis of 10-year results. Rev Bras Ortop. 2009;44(4):306-12.

28. Chen CH, Chuang TY, Wang KC, Chen WJ, Shih CH. Arthroscopic anterior cruciate ligament reconstruction with quadriceps tendon autograft: clinical outcome in 4-7 years. Knee Surg Sports Traumatol Arthrosc. 2006;14(11):1077-85.
29. Adams DJ, Mazzocca AD, Fulkerson JP. Residual strength of the quadriceps versus patellar tendon afte harvesting a central free tendon graft. Arthroscopy. 2006;22(1):76-9.

30. Kyritsis P, Bahr R, Landreau P, Miladi R, Witvrouw E. Likelihood of ACL graft rupture: not meeting six clinical discharge criteria before return to sport is associated with a four times greater risk of rupture. Br J Sports Med. 2016;50(15):946-51.

31. Undheim MB, Cosgrave C, King E, Strike S, Marshall B, Falvey É, et al. Isokinetic muscle strength and readiness to return to sport following anterior cruciate ligament reconstruction: is there an association? A systematic review and a protocol recommendation. British J Sports Med. 2015;49(20):1305-10.

32. Renström P, Arms SW, Stanwyck TS, Johnson RJ, Pope MH. Strain within the anterior cruciate ligament during hamstring and quadriceps activity. Am J Sports Med. 1986;14(1):83-7.

33. Withrow TJ, Huston $\sqcup$, Wojtys EM, Ashton-Miller JA. Effect of varying hamstring tension on anterio cruciate ligament strain during in vitro impulsive knee flexion and compression loading. J Bone Joint Surg Am. 2008;90(4):815-23.

34. Burgi CR, Peters S, Ardern CL, Magill JR, Gomez CD, Sylvain J, et al. MP. Which criteria are used to clear patients to return to sport after primary $\mathrm{ACL}$ reconstruction? A scoping review. Br J Sports Med. 2019; pii:bjsports-2018-099982.

35. Kannus $P$. Ratio of hamstring to quadriceps femoris muscles' strength in the anterior cruciate ligament insufficient knee. Relationship to long-term recovery. Phys Ther. 1988;68(6):961-5.

36. Holcomb WR, Rubley MD, Lee HJ, Guadagnoli MA. Effect of hamstring-emphasized resistance training on hamstring:quadriceps strength ratios. J Strength Cond Res. 2007;21(1):41-7.

37. Slone HS, Romine SE, Premkumar A, Xerogeanes JW. Quadriceps tendon autograft for anterio cruciate ligament reconstruction: A comprehensive review of current literature and systematic review of clinical results. Arthroscopy. 2015;31(3):541-54.

38. Stäubli HU, Schatzmann L, Brunner P, Rincon L, Nolte LP. Mechanical tensile properties of the quadriceps tendon and patellar ligament in young adults. Am J Sports Med. 1999;27(1):27-34 . 